The American Journal of Interdisciplinary Innovations Research

(ISSN - 2642-7478)

VOLUME 04 ISSUE 01 Pages: 16-19

SJIF IMPACT FACTOR (2020: 5. 498) (2021: 5. 676)

OCLC - 1091588944 METADATA IF - 7.895

Crossref doi) 81 Google

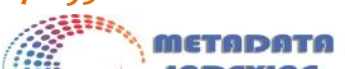

InDExing 5 W WorldCat

Publisher: The USA Journals

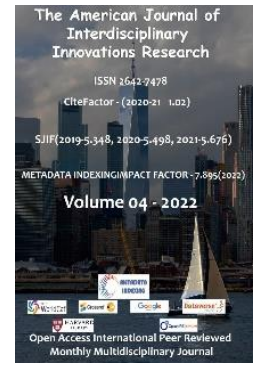

Journal Website: https://theamericanjou rnals.com/index.php/ta jiir

Copyright: Original content from this work may be used under the terms of the creative commons attributes 4.0 licence.
Research Article

\section{PUBLIC OPINION AND GOVERNMENT EVALUATION IN NEW UZBEKISTAN}

\author{
Submission Date: January 09, 2022, Accepted Date: January 20, 2022, \\ Published Date: January 30, 2022 | \\ Crossref doi: https://doi.org/10.37547/tajiir/Volume04lssue01-04
}

Akida Abduzhabbarovna Dadasheva

Professor of the Department of Social Sciences Doctor of Law, Tashkent State Transport University, Uzbekistan

\title{
ABSTRACT
}

This article takes into account the current policy of the Republic of Uzbekistan, the positions and views of citizens on reforms, contacts and dialogue with the authorities. The importance of transparent data generation is recognized. The opinions of great scientists have been recorded and adapted to the present day.

\section{KEYWORDS}

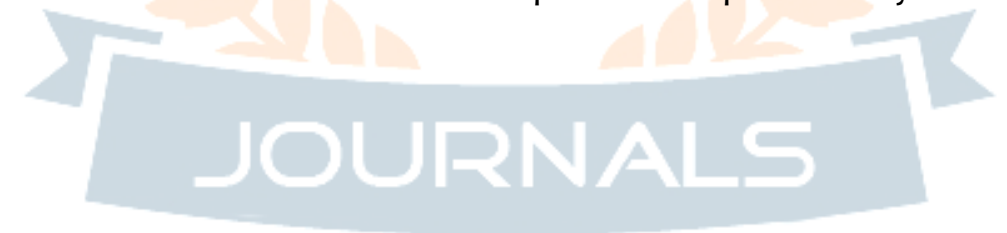

Civil society, public control, reform, legal culture, doctrines, idea, control.

\section{INTRODUCTION}

At the present time, the rapid changes in infrastructure, the growth, development of civilizations and human life are taking place in all countries, as well as in the new Uzbekistan with the themes of reforms. Opinions and forecasts of foreign political scientists provoke controversy among the citizens of Uzbekistan, their debates on this policy are published in the media, interviews, comments are made openly and transparently. The difference is much greater than in some CIS countries [1]. 
The American Journal of Interdisciplinary Innovations Research (ISSN - 2642-7478)

VOLUME 04 ISSUE 01 Pages: 16-19

SJIF IMPACT FACTOR (2020: 5 - 498) (2021: 5 . 676)

OCLC - 1091588944 METADATA IF - 7.895

\section{somet

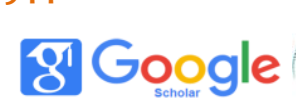

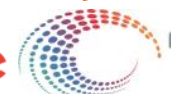

mETอDกTล

5) WorldCat ${ }^{\circ}$ MENDELEY

Publisher: The USA Journals

It is well-known that Uzbekistan has always had its own direction in the history, the policy pursued in the activities of the government. Amir Temur was the founder of the greatest statehood in the Middle Ages, when Uzbekistan raised the culture of statehood and legislation to a new historical stage. Sahibkiran severely punished leaders in his government who did not comply with his demands. At the same time, we emphasize that in the works of our great thinkers Beruni, Ibn Sino, Farobi, Yusuf Khas Khajib, Navoi, Nizami, Jami, efforts were made to understand the problems of social justice and humanism, the formation of human spiritual and moral values. We have inherited ideas, opinions, ideas, doctrines on the assessment of the balance between labor and wages, crime and punishment, rights and obligations [6].

\section{MATERIALS AND METHODS}

Today, in order to fully study the foundations of development and modernization in the Republic, it is necessary to study the factors of its origin. The need to know and understand history, that is, to have knowledge and skills, has been taught by our great ancestors.

In the period of transition of our country to a qualitatively new stage of development, the five directions of the Action Strategy for 2017-2021 and the seven directions of the current Development Strategy for 2022 are interrelated. The changes have left a positive impression not only on our citizens but also on foreign experts. All this highlights the need to study the features of building a democratic, liberal, stable, open and competitive, humane and just rule of law in the outside world, as well as the formation of civil society in our country. Human values are his rights, freedoms and legitimate interests [8].
As we can see, all these issues are still relevant in terms of building a legal and social state. Ensuring the rule of law and equality before the law, the formation of a culture of human rights and respect for the law, socially vulnerable groups, social protection of persons with disabilities, access to education. This is the main idea of the development of the Uzbek state and the ongoing reforms [5].

With the adoption of the Law "On Public Oversight" in 2018, the formation of a strong and just civil society, "knowledge society", "open society" of our citizens, the revision and renewal of old values in society, the implementation of the principles of democratic and sustainable development, human capital is becoming one of the decisive factors of development, characterized by a steady increase in the level of political knowledge and legal culture [7].

It should be noted that in developed countries of the world today the issue of public control over the activities of public authorities in the relationship between the state and society is a topical issue. In the process of democratization of society, strengthening the institutions of civil society, the analysis of the theory of an effective mechanism of public control over the activities of the state, mainly the executive, its types, forms and methods of implementation is not only theoretical but also scientific and practical. In particular, the need for continuous advocacy in the context of public participation in socially important decision-making, the emerging global information society, the process of information and communication technologies, the impact of national mentality and cultural values on the development of civil society and its specificity is important [4].

Public oversight is a key factor in the balance, equality, mutual responsibility and accountability of the individual, society and the state in the administration 
The American Journal of Interdisciplinary Innovations Research (ISSN - 2642-7478)

VOLUME 04 ISSUE 01 Pages: 16-19

SJIF IMPACT FACTOR (2020: 5 - 498) (2021: 5 . 676)

OCLC - 1091588944 METADATA IF - 7.895
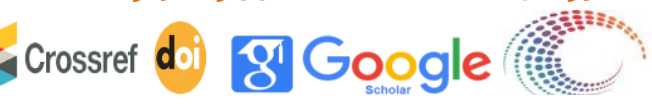

metดDดTด

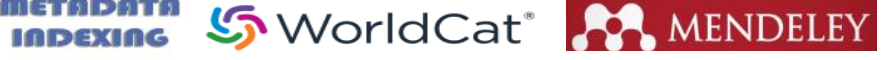

Publisher: The USA Journals

of social justice in society. This institution ensures that human rights and freedoms are not only guaranteed by the state, but also their priority in the activities of public authorities, and the presence of public control is an indicator of the fact that political power is in the hands of the people.

If we go back to our historical titles, we can see in the sources the special attention and teachings of the government and the executive branch, for example, the great thinker Abu Nasr Farobi, the head of state should be so skilled that he should not be an object controlled by someone. Other skills must be subordinated to the governor's management skills. Farobi accepts the above points and tries to find a harmony between politics and government through his thinking. Accordingly, he boldly puts forward the following idea: The noble state is a model of a new type of state, in which the inhabitants of this state will be the owners of true happiness. If a person with theoretical knowledge rules the state, the state will be virtuous, and the Shari'ah should not interfere in politics. The goal of a prosperous state is to establish happiness and justice for all. The distinctive features of a prosperous state are that material things are distributed fairly, and great attention is paid to education and upbringing. According to Farobi, a mature fighter must be a vicious enemy of lies, a lover of wealth, a lover of justice by nature, and a fighter for it and determined [3].

Pay attention to this idea, if the governor has theoretical knowledge, in accordance with the requirements of the time, the noble city and the people living in it will achieve happiness and bliss. It should be considered as one of the main issues of the day.

RESULTS AND DISCUSSION
At the present time, local authorities play a decisive role in ensuring the implementation of local laws and presidential decrees, government decrees issued in accordance with the law. The effective functioning of governors depends in many respects on the extent to which the governance structures of governors meet local needs and are consistent with the new responsibilities. In the context of market relations, authorities are required to have compact, clearly competent and efficient organizational structures.

At the same time, they are represented by experts from the authority, ie active masters of their work who communicate with the media, that is, they convey to the community the correct assessment of the khokim's behavior and try to answer questions from public authorities. Over the past two years, this activity has so far yielded positive results only in the press service of the President [2].

The difference between the concepts of "public control" and "social control" is, first of all, that the concept of "social control" is broader in scope than the concept of "public control". In addition to the concept of "public control", this concept also includes state control and civil control. Because they are essentially manifestations of social control. As a general concept, we define control;

Control is one of the main functions in the process of government activity, civil society institutions create their own influence on the state through their activities aimed at exercising public control. In short, public organizations exercise public control by expressing their views on political and social processes, issues of state and society building, and draft laws and government decisions to be adopted.

Civil society institutions are independent institutions that are formed on their own initiative and self- 
The American Journal of Interdisciplinary Innovations Research (ISSN - 2642-7478)

VOLUME 04 ISSUE 01 Pages: 16-19

SJIF IMPACT FACTOR (2020: 5. 498) (2021: 5 . 676)

OCLC - 1091588944 METADATA IF - 7.895

Crossref dol gु Google (\%)

6. Juraevna, N. N. (2021). Development of Communicative Competence the Youth as a Factor of Affecting Competitiveness (On the Example of Foreign Language Teaching). Pindus Journal of Culture, Literature, and ELT, 9, 73-79.

\section{Normative legal documents}

7. Law of the Republic of Uzbekistan on Public Oversight. No. LRU-474. April 12, 2018.

8. Development Strategy of the New Uzbekistan for 2022-2026.

them. Because it is natural that the successors of our great generations, the followers formed by their teachings on the basis of their ideas, their heritage, correctly assess the policies pursued in the world and apply them in their areas.

\section{REFERENCES}

1. Дадашева А. А. МАХАЛЛИЙ ИЖРО ХОКИМИЯТИ ФАОЛИЯТИ УСТИДАН ЖАМОАТЧИЛИК НАЗОРАТИНИ НАТИЖАДОРЛИГИНИ ОШИРИШНИНГ ИЛМИЙ-НАЗАРИЙ ЕЧИМЛАРИ //ЖУРНАЛ ПРАВОВЫХ ИССЛЕДОВАНИЙ. - 2020. - №. SPECIAL 2.

2. Sh.M.Mirziyoev. New Uzbekistan strategy. Tashkent. 2021.

3. Abu Nasr Farobi. A city of noble people. - T.: Xalq merosi. 1993. - P. 159-160.

4. Акида ДАДАШЕВА. Взаимодейтсвие органов представительной власти на местах и самоуправления граждан в осуществлении действенного общественного контроля // Fuqarolik jamiyari. Гражданское общество 2021, №22. $-70-746$.

5. Matkarimova J.D. Expression of a strong civil society "third sector" // Annali d'Italia. Scientific Journal of Italy Volume 2, № 18 / 2021. - P. 50-51. https://www.elibrary.ru/item.asp?id=45652298 